Kamil Śmiechowski

(Uniwersytet Łódzki

Wydział Filozoficzno-Historyczny

Katedra Historii Polski XIX w.)

\title{
HIERARCHIA CZY DEMOKRACJA? WIZJA STOSUNKÓW SPOLECZNYCH W MIASTACH KRÓLESTWA POLSKIEGO (NA PODSTAWIE DYSKUSJI O SAMORZĄDZIE MIEJSKIM W TRAKCIE REWOLUCJI 1905 ROKU) ${ }^{1}$
}

K westia gotowości elit do udostępnienia szerokiemu kręgowi społeczeństwa możliwości aktywnej partycypacji w życiu publicznym stanowi do demokracji. Uwagę tę, stanowiącą pewien truizm z perspektywy współczesnej, z pewnością można zastosować również do przełomu wieków XIX i XX, kiedy to na skutek doniosłych przemian cywilizacyjnych świat, zwłaszcza szeroko rozumiany świat zachodni, z całą mocą wszedł - jak to określają socjologowie - w epokę późnej nowoczesności, pełną zarówno olbrzymich szans, jak i - jak się wkrótce miało okazać - olbrzymich zagrożeń, jakie niosła ze sobą modernizacja życia społecznego, gospodarki i techniki w połączeniu z nagłym wzrostem popularności nowatorskich ideologii politycznych, obejmujących zarówno socjalizm jak i nowoczesne ruchy narodowe. Był to wszak okres, w którym dokonywały się wszystkie procesy, które klasyk tej tematyki, brytyjski socjolog Anthony Giddens, uważał za konstytutywne dla epoki nowoczesności: oparcie cywilizacji o wytwórczość przemysłową, skomplikowane instytucje gospodarcze, państwa narodowe czy masowe uczestnictwo jednostek w życiu politycznym².

Jednocześnie warto pamiętać, że był to wciąż jeszcze czas, w którym demokracja występowała na kontynencie europejskim w formule, może poza stawianą za ówczesny wzór Francją, na ogół nader ograniczonej oraz silnie zdeterminowanej przez dominujący w wieku XIX w Europie liberalny, burżuazyjny ogląd świata, bardzo mocno uzależniający prawo do partycypacji w życiu publicznym od

\footnotetext{
${ }^{1}$ Artykuł przygotowany w ramach projektu badawczego SONATA 9 „Kwestia miejska u progu nowoczesności. Dyskusja o przyszłości miast w Królestwie Polskim 1905-1914”, finansowanego przez Narodowe Centrum Nauki, realizowanego w Katedrze Historii Polski XIX wieku UŁ. Nr UMO-2014/15/D/HS3/00411.

${ }^{2}$ Zob.: A. Giddens, Nowoczesność i tożsamość, Warszawa 2001, s. 21-23.
} 
posiadanych prestiżu, majątku i wykształcenia ${ }^{3}$. Wątki te były silnie akcentowane również w polskim dyskursie drugiej połowy XIX w. ${ }^{4}$

Wszystkie te okoliczności determinowały oczywiście w pierwszej kolejności kierunki przemian politycznych na szczeblu ogólnopaństwowym, koncertując się wokół takich zagadnień jak pożądana przez poszczególne opcje forma ustroju, kształt parlamentu, problem praw wyborczych, wolności słowa, nietykalności osobistej etc. Istotną kwestią wydaje się wszak także przeanalizowanie tych dysput na nieco niższym szczeblu, a mianowicie w kontekście miejskim, reprezentowanym przez municypalne samorządy i obowiązujący w nich cenzus wyborczy. Takie umiejscowienie moich dociekań do pewnego stopnia wychodzi naprzeciw opinii Manuela Castellsa, który w jednej ze swoich kanonicznych prac podkreślał, iż badaczom relatywnie często umyka gdzieś kwestia wpływu szeregowych mieszkańców miast na historyczny kierunek ewolucji zamieszkiwanych przez nich ośrodków, ich sukcesów i porażek w walce z rozmaitymi formami stosunków społecznych ustanawianymi w każdej epoce historycznej ${ }^{5}$.

Jednakże zwrócenie uwagi na kontekst miejski, sam w sobie szczególnie narażony na konflikty i cechujący się silną dynamiką (co wynika z samej specyfiki środowiska wielkomiejskiego i jego skomplikowania społecznego $)^{6}$, wydaje się istotne zwłaszcza w odniesieniu do Królestwa Polskiego przełomu wieków XIX i XX. Pozostawało ono jednym z ostatnich miejsc na Starym Kontynencie pozbawionym jakiejkolwiek formy miejskiego samorządu, ze skrajnie zaniedbanymi miastami zarządzanymi przez złożone z urzędników niskiego rzędu magistraty podlegające bezpośrednio administracji rządowej, funkcjonujące ponadto $\mathrm{w}$ niejasnym systemie powiązań z lokalnym establishmentem ${ }^{7}$. Jednakowoż ten archaiczny system zarządu miejskiego nie stanowił poważnej bariery w urbanizacji i industrializacji Królestwa, która w okresie po upadku powstania styczniowego, na skutek istotnych przemian społecznych i politycznych, urosła do radykalnych rozmiarów. $Z$ drugiej strony był to zaś czas burzliwych wydarzeń rewolucji 1905 r., które rozpoczynając epokę nowoczesnej polityki na ziemiach polskich

${ }^{3}$ Zob.: R. Nisbet, History of the Idea of Progress, New York 1980, s. 171-297; D. Sdvizkov, Epoka inteligencji. Historia porównawcza warstwy wykształconej w Europie, Warszawa 2011, s. 250-258; I. Wallerstein, The Modern World-System vol. IV. Centrist Liberalism Triumphant 1789-1914, Berkeley -Los Angeles-London 2011.

${ }^{4}$ Zob.: A. Jaszczuk, Spór pozytywistów z konserwatystami o przyszlość Polski 1870-1903, Warszawa 1986; T. Stegner, Liberatowie Królestwa Polskiego 1904-1915, Gdańsk 1990, s. 41-62; M. Janowski, Polska myśl liberalna do 1918 roku, Kraków 1998, s. 157-200.

${ }^{5}$ M. Castells, The City and the Grassroots. A Cross-Cultural Theory of Urban Social Movements, Berkeley and Los Angeles 1983, s. 3.

${ }^{6}$ Por. : D. Harvey, Bunt miast. Prawo do miasta i miejska rewolucja, Warszawa 2012.

${ }^{7}$ Zob.: K. Śmiechowski, Między rzeczywistościa biurokratyzmu a utopia samorządu. Krytyka prasowa miejskiego aparatu urzędniczego w rewolucji 1905 roku na przykładzie Łodzi, [w:] „Dusza urzędnika" - zewnętrzna akceptacja $i$ wewnętrzna niezgoda?: między irredenta a kolaboracją : ugoda, lojalizm i legalizm, red. N. Kasparek, M. Klempert, Olsztyn 2015, s. 105-125. 
i stanowiąc oczywisty skutek przemian ostatnich 40 lat, pod wieloma względami stanowiły rewolucję miejską per se, wykazując wiele analogii z Komuną Paryską roku $1871^{8}$.

Niezależnie od akcentowania miejskiego aspektu wydarzeń lat 1905-1907 podkreślenia wymaga umykająca niekiedy historiografii narodowej skala przeobrażeń społecznych wynikających z procesów urbanizacji i industrializacji Królestwa Polskiego w drugiej połowie XIX w. Jak podkreślała Maria Nietyksza,

w latach 1872-1913 wzrost ludności miejskiej Królestwa był znacznie szybszy od przyrostu ogółu mieszkańców. Podczas gdy ludność Królestwa wzrosła o 75\%, ludność miast potroiła się9.

Jak wiadomo na proces ten, który mimo degradacji ponad 300 najsłabszych ośrodków miejskich do kategorii osad, wywindował odsetek ludności miejskiej Królestwa z niecałych $10 \%$ w latach 70 . XIX w. do ponad 30\% w początkach nowego wieku, wynikał w pierwszej mierze właśnie z uprzemysłowienia, prowadząc do powstania wokół Warszawy, Łodzi i Sosnowca aglomeracji miejsko-przemysłowych, a także rozwoju kilku mniejszych ośrodków (m.in. Częstochowa, Żyrardów $)^{10}$. Podkreślić wypada wreszcie, iż przemysłowy charakter tej urbanizacji, skutkujący intensywnym napływem mas roboczych ze wsi do ośrodków industrialnych, prowadziła do zauważalnej polonizacji ludności miejskiej Królestwa, przejawiającej się w spadku procentowego udziału ludności żydowskiej oraz ewangelickiej ${ }^{11}$.

Świadomość skali procesów urbanizacyjnych prowadziła, jak wiadomo, do co najmniej ambiwalentnej postawy polskich środowisk opiniotwórczych. Jak bowiem podkreślał Andrzej Jaszczuk, spolonizowanie burżuazji oraz sfer przemysłowych, przy jednoczesnym promowaniu polskiej klasy średniej, miało przybliżyć upragniony cel zwolenników programu ,pracy u podstaw” - uczynienie Polski „mieszczańską i laicką"12. Z drugiej strony Bronisława Kopczyńska-Jaworska zaznaczała, że stosunek pozytywistów, podobnie jak i całej inteligencji polskiej, do rozwoju miast i przemysłu był zdeterminowany ich nieświadomym często

\footnotetext{
${ }^{8}$ Teza o rewolucji 1905 r. jako rezultacie forsownej urbanizacji Królestwa Polskiego po upadku powstania styczniowego zyskuje uznanie badaczy zwłaszcza w ostatnich latach. Zob.: R.E. Blobaum, Rewolucja: Russian Poland 1904-1907, Ithaca 1995, s. 18-28; S. Ury, Barricades and Banners. The Revolution of 1905 and the Transformation of the Warsaw Jewry, Stanford 2012; K. Śmiechowski, Searching for the better city: urban discourse during the Revolution of 1905 in the Kingdom of Poland, „Praktyka Teoretyczna” nr 3(13)/2014, s. 71-96, http://www.praktykateoretyczna.pl/PT_nr13_2014 _Archeologies/04.Smiechowski.pdf, DOI 0.14746/pt.2014.3.4 (dostęp - 15.12.2015).

${ }^{9}$ M. Nietyksza, Rozwój miast i aglomeracji miejsko-przemystowych w Królestwie Polskim 1865-1914, Warszawa 1986, s. 139.

${ }^{10}$ Tamże, s. 335-336.

${ }^{11}$ Tamże, s. 206-245.

${ }^{12}$ A. Jaszczuk, Spór ..., s. 147-149.
} 
przywiązaniem do tradycyjnej kultury szlacheckiej ${ }^{13}$. Przełom antypozytywistyczny, który dokonał się w Królestwie z początkiem lat 90. XIX w., objawiający się „ludomanią" i związanym z nią szybkim rozwojem ruchu narodowego, wzmógł jeszcze antyurbanistyczne nastroje elit ${ }^{14}$. Podkreślając paradoks tej sytuacji Jerzy Jedlicki zwracał jednakowoż uwagę, że polskie mieszczaństwo pomimo wszystkich zastrzeżeń pozostawało jednak o wiele bardziej mieszczańskie niż polskie, „siłą rzeczy” nasiąkało więc miejską kulturą i przyjmowało miejski styl życia, a antyurbanizm polskich elit miał też głębokie europejskie podłoże ${ }^{15}$. Doniosłość tych przemian widoczna była w szczególności właśnie w zmianie zachowań wciąż bardzo przecież związanych ze swoim pierwotnym środowiskiem wiejskim robotników, dla których - jak się zdaje - przenosiny z terenów wiejskich do Warszawy czy Łodzi same w sobie oznaczały równie duży awans cywilizacyjny co rezygnacja z pracy na roli na rzecz pracy w fabryce. Magdalena Gawin słusznie zauważa:

etnolodzy podkreślają, że wraz z kształtowaniem się wielkomiejskiego proletariatu robotnicy zaczęli świadomie dystansować się wobec stylu życia chłopskiego. [...] Posiadanie odświętnego ubrania - białej koszuli, krawata, marynarki z kamizelką i eleganckich butów - znacznie zwiększało prestiż robotnika i umacniało jego miejską tożsamość. Na początku XX w. odświętnie ubrana robotnica nie odróżniała się już od urzędniczki, nauczycielki czy sprzedawczyni ze sklepu. [...] Obserwator życia społecznego, Aleksander Wóycicki, pisał o robotnikach łódzkich: „To już dzieci miasta, fabryki, trotuarów miejskich, podobnie jak rodzice ich byli dziećmi wsi polskiej”'16.

Obserwując królewiacki dyskurs z przełomu wieków, przepełniony ostrą krytyką mieszczaństwa i jego przywar, nietrudno o wniosek, że ów antyurbanizm pozostawał jednak bardzo często pewną pozą stylistyczną, mającą wymiar ściśle dydaktyczny. Odwołując się do obywatelskich obowiązków sfer lepiej sytuowanych, próbując scementować społeczność czytelników wokół pojawiających się co i rusz projektów i zamysłów, wskazywano wszak na obserwacje realnych problemów, z którymi borykały się miasta Królestwa. W prasie łódzkiej taki oparty o szantaże moralne styl przekonywania miał charakter dominujący ${ }^{17}$. Podobnie ciągła i często silnie przejaskrawiona krytyka inteligencji prowincjonalnej, stanowiąca bardzo silny element dyskursu publicznego w Królestwie począwszy

\footnotetext{
${ }^{13}$ B. Kopczyńska-Jaworska, Miasto i miejskość w systemie wartości Polaków, [w:] Miasto i kultura polska doby przemystowej. Wartości, red. H. Imbs, Wrocław-Warszawa-Kraków 1993, s. 101, 103.

${ }^{14}$ Temat ten podejmuje wiele autorek i autorów w tomie Mieszczaństwo i mieszczańskość w literaturze polskiej drugiej połowy XIX wieku, red. E. Ihnatowicz, Warszawa 2000.

${ }^{15}$ J. Jedlicki, Proces przeciwko miastu, [w:] tenże, Świat zwyrodniały. Lęki i wyroki krytyków nowoczesności, Warszawa 2000, s. 83-113.

${ }^{16}$ M. Gawin, Przemiany cywilizacyjne na ziemiach polskich w XIX wieku, [w:] Historie Polski w XIX wieku, red. A. Nowak, t.1: T. Epsztein, M. Gawin, B. Dopart, Kominy, ludzie i obłoki: modernizacja i kultura, Warszawa 2013, s. 224.

${ }^{17}$ Zob.: K. Śmiechowski, Łódzka wizja postępu. Oblicze społeczno-ideowe „Gońca Łódzkiego”, „Kuriera Łódzkiego” $i$ „Nowego Kuriera Łódzkiego” w latach 1898-1914, Łódź 2014, s. 61-99.
} 
od lat 70. XIX w., miała przecież na celu nie tyle deprecjonowanie, co raczej - poprzez ciągłe upominanie - pobudzanie pozawarszawskich ośrodków do wzmożonej aktywności obywatelskiej ${ }^{18}$.

Na tym tle w ostatnich dekadach XIX w. nastąpił prawdziwy rozkwit publicystyki ${ }^{19}$ oraz literatury fachowej poświęconej problematyce miejskiej, skupionej na wskazywaniu bolączek ustroju gospodarczego miast Królestwa ${ }^{20}$. Jej autorami bywali wyśmienici znawcy problematyki społeczno-ekonomicznej, m.in. Adolf Suligowski, Władysław Grabski czy Stanisław Koszutski. O poglądach prezentowanych przez tych ekspertów świadczą słowa ostatniego z wymienionych, wypowiedziane w jego pracy z okazji ostatecznego wprowadzenia samorządu w okupowanym Królestwie w 1915 r. Zdaniem tego wziętego publicysty ekonomicznego,

wyższość samorządu lokalnego w sprawach blisko związanych z potrzebami życia „miejscowego" nad biurokratycznym systemem zarządzania tymi sprawami da się łatwo uzasadnić już a priori [sic! - K.Ś.], została zaś dowiedziona praktyką wieloletnią tych państw, które wyrzekając się systemu bezwzględnej centralizacji administracyjnej, przekazały bezpośrednie kierownictwo „sprawami miejscowymi” instytucjom samorządnym ${ }^{21}$.

Konieczność wprowadzenia samorządu miejskiego w Królestwie Polskim nie była zatem tematem nowym w roku 1905, a przed szerszym wypowiadaniem tego dezyderatu powstrzymywać zdawał się jedynie system cenzury prewencyjnej, mocno ograniczający, jeśli nie uniemożliwiający krytykę władz. Świadomość konieczności dokonania zmian dobrze ilustruje chociażby artykuł, który ukazał się w „Prawdzie” już po rządowej zapowiedzi nadania samorządu miastom Królestwa, w październiku 1905 r. Jak przekonywał felietonista tego tygodnika ewentualna reforma, „o której piszą wiele, mnóstwo nadziei w niej pokładają” była niezbędna, gdyż dotychczasowe magistraty były jedynie ,śmieszną karykaturą instytucji samorządowych”, zaś ,,wybór radnych i ławników miast naszych to coś, czego sam Mark Twain by nie mógł wymyśleć”. Powołując się na „potworne cyfry stosunku wydatków miejskich na oświatę wraz ze wszystkimi celami kulturalnymi do wydatków administracyjnych" Kalisza; przypominając, że

przeszło 400-tysięczna Łódź na próżno czeka na kanalizację, stutysięczny Sosnowiec - na bruki, a są miasta dziesięciotysięczne, jak Zamość, które nie mogą w ciągu lat dwudziestu kilku przenieść do miasta urzędu pocztowego odległego o trzy wiorsty,

\footnotetext{
${ }^{18} \mathrm{~A}$. Szwarc, Inteligencja warszawska i prowincjonalna w świetle własnych opinii z lat popowstaniowych, [w:] Inteligencja polska XIX i XX wieku. Studia, red. R. Czepulis-Rastenis, t. 3, Warszawa 1983, s. $187-215$.

${ }^{19}$ Np.: S. Gorski, Łódź spółczesna. Obrazy i szkice publicystyczne, Łódź 1904.

${ }^{20}$ Np.: B. Bouffałł, Organizacja miast w Królestwie Polskim, [w:] W naszych sprawach. Studia w kwestiach ekonomiczno-społecznych, Warszawa 1899, s. 149-215.

${ }^{21}$ S. Koszutski, Nasze miasta a samorzą (życie miast w Królestwie Polskim a reforma samorzadowa), Warszawa 1915, s. 15.
} 
autor konkludował, iż przed „radykalną reformą” byłoby „co najmniej lekkomyślnością" marzyć by magistraty mogły skutecznie wziąć na swe barki wielki ciężar odbudowy szkolnictwa elementarnego ${ }^{22}$.

Skoro zatem, jak widać z powyższych wypowiedzi, oczekiwanie wprowadzenia w miastach Królestwa samorządu wzorowanego na powszechnej już wówczas praktyce miast zachodnich wydawało się bezdyskusyjne, warto przeanalizować stopień demokratyzacji samorządu, na jaki gotowi byli zgodzić się uczestniczący w dyskusji na ten temat, a także społeczne podłoże pojawiających się różnic poglądów i kontrowersji. W tym celu omówię argumentację głównego autora pierwszego projektu ustawy, Adolfa Suligowskiego, następnie zaś skupię się na polemice, jaką wywołały przyjęte w projekcie założenia wśród przedstawicieli czołowych ugrupowań politycznych - postępowców, endecji i socjalistów. Swój wywód osadzę o ogólną wizję miast i samorządu w ideologii tych stronnictw, zrekonstruowaną częściowo na przykładzie innych ich wystąpień z epoki, tak w prasie partyjnej, jak i w komercyjnych gazetach łódzkich i warszawskich.

Warto przy tym podkreślić, iż wnioski, które możemy wysnuć z tych debat wydają się przy tym odpowiadać pewnym ogólnym założeniom wynikającym z ówczesnego stadium rozwojowego wiodących ideologii politycznych i społecznych. Analiza dyskursu toczącego się na tle prac nad samorządem miejskim w Królestwie w czasie rewolucji 1905 r. i w latach następnych pozwala bowiem na wyodrębnienie trzech dominujących logik, wokół których - jak wierzono - powinny zostać zorganizowane stosunki społeczne pomiędzy poszczególnymi grupami ludności miejskiej.

Najstarszą z nich była logika liberalna (można też ją określić mianem burżuazyjnej lub po prostu mieszczańskiej), która w sporej mierze zdawała się być kontynuacją dotychczasowego, (post-) pozytywistycznego jeszcze sposobu objaśniania podziałów społecznych. Jego przykładem może być wywód jednego z łódzkich publicystów na temat - co istotne w kontekście miejsca, w którym go opublikowano - charakteru podziałów klasowych w społeczeństwie:

Stosunki teraźniejsze między pracodawcą a podwładnym u nas w Łodzi szczególniej wyodrębniają się i są tak jaskrawe, że zasługują na uogólnienie.

[...] Dawniej każdy pracownik był także płatny, a jednak inaczej uważany. Dziś całym staraniem pryncypała jest, ażeby podwładny dostał w określonym czasie przeznaczoną zapłatę, poza tym uważany jest li tylko za przedmiot na równi stojący z innymi przeznaczonymi do funkcji w życiu społecznym. Wszelkie wnikanie w potrzeby pracowników, badanie lub śledzenie za jego życiem domowym lub poza spełnionymi obowiązkami, uważa się już dziś za sentymentalizm zupełnie bezużyteczny a nawet śmieszny. Zrobiłeś swoje, dostałeś za to określoną kwotę pieniędzy, bądź więc zadowolony.

${ }^{22}$ J. Dąbrowski, Rachunki spoteczne, „Prawda”, 28 X 1905, nr 42, s. 492. 
Takie załatwienie kwestii jest bardzo wygodne dla jednej strony, nie licuje jednak z obowiązkami, jakie każdy pracodawca musi mieć na względzie jako członek społeczeństwa. Mieć pracownika zapłaconego to jeszcze mało. Prócz zaspokojenia swych potrzeb materialnych, pracownik winien odczuwać, że praca jego znajduje uznanie, mieć bodźca w tym, że to co robi, przynosi korzyść, on pragnie być uważanym za cząstkę interesu nie tylko materialną, ale spojoną węzłami ludzkich uczuće ${ }^{23}$.

Podkreślić trzeba silny paternalizm wynikający z takiego postawienia sprawy. Łódzkie pismo zdawało się twierdzić, że wyzysk ekonomiczny, którego doświadczała społeczność robotnicza, miał wynikać nie tyle z elementarnych różnic interesów między burżuazją, a klasą robotniczą, co raczej z braku zrozumienia dla obowiązków obywatelskich oraz społecznych. Robotnicy mieli natomiast być nie tyle ofiarami konfliktu między pracą, a kapitałem, co ofiarami samych żądnych zysku kapitalistów. Co więcej, prezentowana w powyżej cytowanej opinii wiara w nieklasowy de facto charakter stosunków społecznych musiała sprzyjać preferowaniu ewolucyjnych rozwiązań24 ${ }^{4}$.

Jeśli jednak liberałowie odrzucali pogląd o antagonistycznym charakterze stosunków społecznym to jak rozumieli demokratyzację społeczeństwa, a co za tym idzie, jakie cele stawiali przed samorządem miejskim? Na to pierwsze pytanie przekonująco odpowiedział Tadeusz Stegner:

liberałowie pojęcie demokracji i demokratyzacji życia rozumieli znacznie szerzej niż żądanie czteroprzymiotnikowego prawa wyborczego i w ten sposób zapewnienia władzy ludu. Dla nich rozwój demokracji związany był z rozwojem kultury, tworzeniem instytucji demokratycznych takich jak organizacje kulturalno-oświatowe, samorządy, spółdzielnie, bezpartyjne związki zawodowe ${ }^{25}$.

Logika liberalna, znalazła swe odzwierciedlenie przede wszystkim w opracowanym przez związanego w owym czasie z petersburskimi realistami Adolfa Suligowskiego, redaktora powstałego w wyniku prac specjalnej komisji powołanej przez generał-gubernatora warszawskiego „polskiego” projektu ustawy miejskiej dla Królestwa z 1906 r. $^{26}$, pozostającego w trakcie prac na projektem pod wpływem znanego konserwatywnego historyka i prawnika Aleksandra Rembowskiego. Kluczowym elementem projektu było - w ocenie samego autora, który opublikował obszerne Motywy ${ }^{27}$ do projektu - przekonanie o edukacyjnej funkcji przyszłego samorządu, która miała zostać spełnioną przez z jednej strony zasadę głoszącą iż „dostęp do tych instytucji ma być wolny dla przedstawicieli wszystkich warstw ludności miejskiej, bez żadnych ograniczeń co do stanu, pochodze-

${ }^{23}$ K. Halinka, Chiński mur, „Goniec Łódzki”, 21 VIII/2 IX 1899, nr 54.

${ }^{24}$ K. Śmiechowski, Łódzka wizja..., s. 123-124.

${ }^{25}$ T. Stegner, Liberatowie ..., s. 45-46.

${ }^{26}$ Projekt ustawy miejskiej dla miast Królestwa Polskiego z r. 1906, [w:] A. Suligowski, Pisma, t. 1: Potrzeba samorzadu, Warszawa 1915, s. 137-185.

${ }^{27}$ Motywy do projektu ustawy miejskiej dla miast Królestwa Polskiego, [w:] tamże, s. 91-115. 
nia i wyznania”. Jednocześnie jednak dostęp ów miał być „powierzony ludziom wiedzy i doświadczenia w sprawach potrzeb miejskich”28.

Ta pozorna sprzeczność znalazła swoją realizację w przepisach szczegółowych. Silne przekonanie o hierarchiczności stosunków społecznych miało być potwierdzone jeszcze w podziale wyborców na kurie - do pierwszej, wybierającej połowę głosów - zaliczani mieli być

poważni kontrybuenci podatków miejskich jako to - właściciele domów, jako też osoby z cenzusem naukowym wyższym i średnim, zaś w Warszawie i Łodzi, jako w wielkich centrach miejskich, obok właścicieli domów, jedynie osoby, które ukończyły kursa w wyższych zakładach naukowych, a także wybitni przedstawiciele wielkiego przemysłu i handlu.

Kolejne drastyczne ograniczenie liczby uprawnionych do głosowania, jakie byłoby konsekwencją tego rozwiązania, znajdywało takie wytłumaczenie ze strony autora projektu:

upłynęło lat 88 od czasu zwinięcia w kraju naszym samorządu miejskiego - śladu po nim nie pozostało. Społeczeństwo polskie pod uciskiem systemu biurokratycznego, będąc usunięto od wszelkiego udziału w zarządzie kraju, pozbawione zostało wszelkiej możliwości rozwijania swych sił w tym właśnie kierunku, wskutek czego warstwy niższe ludności są do tego nieprzygotowane. Z powodu tego nieprzygotowania, udział ich w instytucjach samorządowych miejskich wymaga pewnej korekty przynajmniej do czasu, w postaci zapewnienia warstwom więcej uświadomionym pracy samodzielnej w instytucjach samorządowych miejskich ${ }^{29}$.

Drugim filarem konstytuującym wizję przyszłego samorządu było wyeliminowanie zeń analfabetów. Warunkiem posiadania prawa wyborczego miało być zatem posiadanie na swoje imię mieszkania w mieście pod warunkiem umiejętności czytania i pisania. Jak tłumaczył Suligowski, analfabetyzm miał równać się kalectwu, w zasadzie uniemożliwiając podejmowanie racjonalnych decyzji wyborczych.

Ażeby wykonać należycie prawo wyborcze, bądź czynne, bądź też bierne - przekonywał - niepodobna jest obejść się bez pewnego przygotowania i odpowiednich wiadomości, a więc, ze stanowiska ogólnego dobra, dopuszczenie analfabetów do współudziału nie może być usprawiedliwione. Wszelako i ze stanowiska interesu osobnika, również nie może być uznane za niezbędne: wszak w interesie analfabety leży nie jego udział w wyborach, ale raczej właśnie uwolnienie go od tej dolegliwości moralnej, której podlega ${ }^{30}$.

Argumenty te, choć oczywiście były racjonalne, pociągały jednakowoż za sobą bardzo dalekosiężne konsekwencje w postaci wykluczenia z głosowania w zależności od miasta od połowy do nawet - tak jak w Łodzi - 80\% populacji, z których zdawać musieli sobie sprawę tak Suligowski jak i inni zwolennicy projektu.

\footnotetext{
${ }^{28}$ Tamże, s. 93.

${ }^{29}$ Tamże, s. 99.

${ }^{30}$ Tamże, s. 98.
} 
Oczywiście wykluczenie analfabetów z wyborów było silnie osadzone w klasycznej XIX-wiecznej wersji liberalizmu, ściśle wiążącego uprawnienia z poziomem awansu społecznego. Liberałowie, a takimi byli wszak pozytywiści warszawscy, wierzyli, iż w miarę rozwoju edukacji i upowszechniania się postępu kompetencje wymagane do świadomego wykonywania praw obywatelskich ,spłyną” z wyższych na niższe warstwy społeczeństwa. $Z$ tego też powodu w logice Suligowskiego, uderza przekonanie, że owszem, robotnik miał prawo głosować, a nawet być wybieranym jedynie wtedy, gdy poprzez swoje wykształcenie zbliżył się mentalnie do warstw wyższych, zwłaszcza zaś miejskiej inteligencji, która winna być niejako predestynowana do odgrywania wiodącej roli w życiu politycznym miasta. Znamienne, że założenia, które stały za rozumowaniem Suligowskiego znajdywały zrozumienie nie tylko w kręgach inteligencji, ale również i u niektórych przedstawicieli wielkiej burżuazji. W 1905 r. najaktywniejszy z grona łódzkich przemysłowców, Juliusz Kunitzer, przekonywał:

W wyborach do rady miejskiej czynny współudział powinni brać nie tylko właściciele domów, ale i lokatorzy przynajmniej już poczynając od 500 rubli (sic! - K. Ś.) rocznego komornego. Można śmiało powiedzieć, że w wielu przypadkach lokatorzy bardziej dbają o dobro miasta, niż zmaterializowani do głębi kamienicznicy. Tu interes społeczny winien odgrywać rolę decydującą; byłoby więc wysoce szkodliwym i niesłusznym dopuszczać do głosu wyborczego jedynie właścicieli domów.

[...] Jednostek dzielnych i rozumnych znajdziemy z pewnością bardzo wiele. Będą też kandydaci i na prezydenta i na wiceprezydentów. Trzeba jedynie zabiegać o to, aby do przyszłej rady weszli w większości ludzie inteligentni, trzeba wybierać lekarzy, adwokatów, abyśmy twardą stanęli stopą, no i nie mieli nadmiaru przemysłowców, którzy zbyt mało rozporządzają czasem do poświęceń społecznych. Pracy będzie wiele, za dużo nawet, wszystko trzeba organizować - pochłonie to wiele trudów i kłopotów. Na to trzeba być z góry przygotowanym ${ }^{31}$.

Samorząd, mimo swej funkcji narzędzia demokratyzacji i nośnika postępu, miał zatem w logice liberalnej stanowić zarazem odzwierciedlenie silnych podziałów społecznych o charakterze stratyfikacyjnym, tzn. uzależnionych od miejsca poszczególnych jednostek w drabinie społecznej, przede wszystkim zaś stopnia ich przygotowania do prawidłowego wypełniania powinności obywatelskich.

$\mathrm{Na}$ tle tego, co wyżej napisano ciekawie przedstawia się stosunek do projektu samorządu prezentowany przez środowiska związane z narodową demokracją. Jak wiadomo, twórcy ruchu narodowego zajmowali na ogół dość wstrzemięźliwe stanowisko wobec modelu rozwoju nowoczesnych społeczeństw kapitalistycznych i roli, jaką odgrywała w nim urbanizacja. Jan Ludwik Popławski, jak zwracała uwagę Teresa Kulak, był gorącym krytykiem stosunków panujących między pracodawcami a pracownikami w uprzemysłowionych okręgach Królestwa

${ }^{31}$ W przededniu samorzadu miejskiego, „Rozwój”, 4 X/21 IX 1905, nr 221. 
- łódzkim i zagłębiowskim. Będąc szczerze zatroskanym o los robotników, silnie łączył on jednak wyzysk, którego doświadczali, ze stosunkami etnicznymi panującymi w Łodzi czy Sosnowcu. Wyzysk robotników był dlań wyzyskiem proletariatu przez kapitalistów na równi, a może nawet i w pierwszym rzędzie, z wyzyskiem ubogiego i nieuświadomionego polskiego ludu przez bogatą i wykształconą burżuazję niemiecką i żydowską. Z powyższych względów wielokrotnie określał się mianem ,antyindustrialisty”, przestrzegając jednocześnie przed naiwną chłopomanią, konserwującą zacofanie Królestwa wobec Europy ${ }^{32}$.

Nieco mniej zniuansowana była postawa innego z wielkich ideologów prawicy, Romana Dmowskiego, który na przełomie wieków wyrósł na niekwestionowanego przywódcę rodzącego się ruchu. Grzegorz Krzywiec pisze, iż Dmowski

oddziaływanie wielkiego, industrialnego miasta na współczesnego człowieka porównywał do znanego na morzach północnych prądu wodnego - malstromu, „szalonego wirowiska, w którym najsilniejsze statki giną bez ratunku. Żeglarze z daleka je omijają, bo wiedzą, że gdy okręt dostanie się w sferę działania Malstormu nic go nie ocali; pędzi z okropną szybkością w lejkowatą głębię odmętu, w której wściekła siła kruszy go na drzazgi. Złowrogi huk tego oceanicznego piekła rozlega się daleko, jakby ostrzegając nieostrożnych żeby się zanadto nie zbliżali" ${ }^{33}$.

Przy tak silnej tendencji antyurbanistycznej wydawałoby się, że samorząd miejski nie powinien być głównym przedmiotem zainteresowania endecji w trakcie rewolucji, a już na pewno nie powinien być za nadto demokratyczny.

Pierwsze wrażenie, jakie przynosi lektura pochodzących głosów z tej strony dyskursu społeczno-politycznego, wydaje się wszak zaskakujące. Sympatyzująca $z$ endecją prasa wykazywała bowiem żywe zainteresowanie tematem. Silnie powiązany z Narodową Demokracją łódzki dziennik „Rozwój” nie wahał się pisać, że „obok wyborów, najważniejszą dziś sprawą dla nas jest sprawa przyszłego samorządu miejskiego i ziemskiego" 34 .

Zaskakiwać może również stosunek niektórych przedstawicieli endecji do projektu przygotowanego przez Suligowskiego. Przeciwko ograniczeniom w nim zawartych otwarcie wystąpił bowiem na łamach „Kuriera Warszawskiego”, największej gazety Królestwa, Władysław Studnicki. Ów były socjalista, w trakcie rewolucji będący już działaczem aktywnym Narodowej Demokracji, nie miał wątpliwości, iż

samorząd miejski musi być oparty na szerokiej podstawie demokratycznej, aby mógł doznawać zaufania szerokich warstw ludności, aby mógł łączyć przedstawicieli różnych warstw przy wspólnej pracy społecznej.

${ }^{32}$ T. Kulak, Jan Ludwik Popławski. Biografia polityczna, Wrocław-Warszawa-Kraków 1994, s. $111-113$.

${ }^{33}$ G. Krzywiec, Szowinizm po polsku. Przypadek Romana Dmowskiego (1866-1905), Warszawa 2009, s. 157.

${ }^{34}$ W przededniu samorządu miejskiego, „Rozwój”, 4 X/21 IX 1905, nr 221. 
Jak przekonywał,

chcąc uczynić samorząd miejski organem wszystkich warstw ludności, należy, wzorem Anglii, udzielić prawa wyborczego wszystkim, wynajmującym lokal osobny.

Jak jednoznacznie dodawał,

projektu p. Suligowskiego wytworzenia kół inteligencji wyższej i zwykłych mieszkańców nie uznajemy za zbyt fortunny. Jest to zasada kurii, które nie całkują społeczeństwa, ale zaostrzają antagonizmy między poszczególnymi grupami jego. Kandydujący wobec pewnego grona wyborców uwzględnia tylko ich pojęcia i interesy, gdy kandydat, stający wobec różnych grup społecznych, poszukiwać winien interesów wspólnych tych grup, stosować się do ogólnych społecznych i narodowych interesów ${ }^{35}$.

Tyrada Studnickiego traci jednak owe intrygujące oblicze, gdy przyjrzeć się bliżej endeckiemu rozumieniu pojęcia „ogólnych i narodowych interesów”, na jaką powołał się autor. Katarzyna Wrzesińska, wytrawna badaczka ideologii Narodowej Demokracji, podkreśla, że reprezentanci tego stronnictwa, choć - podobnie jak liberałowie - uważali przewodnią rolę inteligencji w społeczeństwie za bezdyskusyjną, to jednakowoż zupełnie inaczej wyobrażali sobie rolę jednostek w procesie demokratyzacji społeczeństwa. Jak pisze ta autorka, narodowi demokraci

istoty demokratyzmu upatrywali przede wszystkim $\mathrm{w}$ emancypacji warstw ludowych i w przyznaniu ogółowi ludności równych praw, w likwidacji barier kulturowych i uczestnictwie ogółu społeczeństwa w życiu narodu.

Demokratyzacja miała zatem dokonać się „nie poprzez głoszenie «zasady wszechwładztwa ludu»”, lecz „wciągnięcie tego ludu” w służbę interesom narodowym realizowanym za pomocą instytucji przyszłego, niepodległego państwa ${ }^{36}$. W odróżnieniu od liberałów różnych denominacji - „postępowców” i „realistów”, endecy nie uważali za zasadne odgradzanie niższych warstw społeczeństwa od jego elit. Próbowali znieść ten podział poprzez odwołanie się do rzekomo integrującej ogół idei narodu ${ }^{37}$.

Przekładając to na kontekst miejski i omawiane dyskusje na temat samorządu, powiedzieć trzeba zatem, że członkowie i sympatycy Narodowej Demokracji nie obawiali się mas odbierających inteligentom miejsca w przyszłym samorządzie. Przeciwnie, raczej chcieli zabiegać o ich głosy, a rękojmie sukcesu widzieli w uświadomieniu narodowym robotników, którzy - już jako pełnoprawni przedstawiciele narodu - umieliby „ocenić należycie” położenie społeczeństwa

${ }^{35}$ Wł. Studnicki, Samorząd miejski w Królestwie, „Kurier Warszawski”, 11 I 1906, nr 11.

${ }^{36}$ K. Wrzesińska, Kultura i cywilizacja w myśli Narodowej Demokracji (1893-1918). Między idea wychowania a polityka, Warszawa 2012, s. 97-98.

${ }^{37}$ Zob. też: N. Bończa-Tomaszewski, Demokratyczna geneza nacjonalizmu. Intelektualne korzenie ruchu narodowo-demokratycznego, Warszawa 2001. 
i wybrać „najodpowiedniejszą drogę” ich realizacji13. Ów specyficzny stosunek do demokratyzacji był zatem silnie osadzony w ideologii ruchu narodowego, który w owym czasie powoli stawał się - kosztem liberałów i w opozycji do socjalistów - cichym wygranym wciąż jeszcze toczącej się rewolucji. Towarzyszył temu proces narastającej niechęci Dmowskiego i innych działaczy endecji do zaktywizowanych $\mathrm{w}$ trakcie rewolucji mas i sposobu uprawiania przez nie polityki (nazywanego przez autora „Myśli nowoczesnego Polaka” mianem „syfilisu politycznego"), zredukowanych potem w ich myśleniu do kategorii thumu, który należało ponownie poddać kontroli i chaosu, nad którym należało zapanować. Polem, który miał umożliwić to ponowne odpodmiotowienie thumów poprzez ich ponowne osadzenie „na właściwym szczeblu” hierarchii społecznej, miał być właśnie interesownie skonstruowany ethnos ${ }^{39}$.

Jedna z najoryginalniejszych prezentacji powyższego procesu pojawiła się jednak nie na łamach oficjalnych teoretycznych periodyków partyjnych, lecz w cytowanym już łódzkim „Rozwoju”40 i wyszła spod pióra Stanisława Łąpińskiego. W listopadzie 1907 r. tak pisał on o społecznych potrzebach miasta i sposobach ich zaspokojenia:

Rozbudzone z długiego uśpienia życie społeczne, obnażyło tyle ran, tyle niedomagań, ujawniło tyle potrzeb, że jeżeli komu, to nam w słodkim niebycie pogrążać się nie wolno.

Życie domaga się od nas wytężonej pracy, od której nikomu z nas uchylić się nie godzi pod grozą surowej odpowiedzialności wobec przyszłych pokoleń, którym spuściznę wziętą po dziadach i ojcach, pomnożoną własnym dorobkiem przekazać musimy.

A cóż im przekażemy?

Zdziczenie obyczajów, upadek moralności, splugawienie najcenniejszych ideałów ludzkości, zwyrodniały postęp.

Uporządkować się więc przede wszystkim musimy u siebie w domu, odrodzić moralnie i materialnie.

Do tej pracy wszelako przystąpić należy z gorącą wiarą w siebie i lepsze instynkty naszego ludu, co umiejętnie pokierowany (sic! - K.Ś.), stać się może niezachwianą podwaliną naszej pracy twórczej, pracy dla przyszłych pokoleń, naszego duchowego odrodzenia.

Łódź szczególniej tego uporządkowania potrzebuje.

Życie jej społeczne, skłócone do głębi więcej może, niż w jakiejkolwiek innej miejscowości kraju wyrzuciło na powierzchnię mnóstwo mętów i szumowin, z których oczyścić je trzeba.

${ }^{38}$ K. Wrzesińska, Kultura ..., s. 71.

${ }^{39} \mathrm{~W}$. Marzec, Modernizacja mas. Moment polityczny i dyskurs endecji w okresie rewolucji 1905-1907, „Praktyka Teoretyczna” 2014, nr 3(13), s. 99-131, http://www.praktykateoretyczna.pl/ PT_nr13_2014_Archeologies/05.Marzec.pdf, DOI 10.14746/pt.2014.3.5 (dostęp - 19 XII 2015).

${ }^{40} \mathrm{O}$ stosunku tego prawicowego dziennika do wydarzeń rewolucyjnych lat 1905-1907 zob.: „Wolność czy zbrodnia?” Rewolucja 1905-1907 roku w Łodzi na łamach gazety „Rozwój”, oprac. M. Sikorska-Kowalska, Łódź 2012. 
Dzieła zaś tego niezwykle trudnego i mozolnego dokonać możemy skutecznie tylko na drodze wytrwałej, dobrze zorganizowanej i celowo prowadzonej pracy pokojowej, nad podniesieniem poziomu etycznej kultury w naszym mieście, złagodzeniem obyczajów jego ludności, uobyczajnieniem jej towarzyskim, tępiąc przy tym analfabetyzm, prostując zmącone pojęcia i poglądy, podnosząc dobrobyt, rozwijając szkolnictwo, słowem szczepiąc we wszystkich kierunkach ideały pracy, sprawiedliwości i umiłowania rzeczy podniosłych ${ }^{41}$.

Cele te zrealizowane miały być w domu ludowym, stanowiącym coś w rodzaju prowadzonej pod kierunkiem inteligencji placówki kulturalnej, mającej na celu łączenie edukacji klasy robotniczej z jej indoktrynacją do polskości. Zdaniem Łąpińskiego ,życie towarzyskie kształci młodzież płci obojga do przyzwoitego traktowania się nawzajem, do bacznej uwagi na postępowanie i prowadzenie się w ogóle, rozwija przymioty towarzyskie, a więc przyczynia się wielce do łagodzenia obyczajów i może najenergiczniej odciąga młodzież od knajp i knajpeczek i pokrewnych im nor i jaskiń, gdzie lękną się gady rozpusty i zwyrodnienia obyczajów"42. Nie ulegało wątpliwości, że prawdziwym zadaniem tegoż domu ludowego miałoby być odciąganie robotników nie tylko od niskich obyczajów, ale przede wszystkim od rewolucji i samodzielnej aktywności politycznej.

Obie zaprezentowane wyżej logiki tj. liberalna i solidarystyczna ustanawiały wizję harmonii społecznej opartej albo o organiczny ład społeczny, albo o łączącą jednostki ponad występującymi pomiędzy nimi oczywistymi podziałami ekonomicznymi wizję wspólnoty narodowych interesów. Abstrahując od oczywistej utopijności tych poglądów podkreślić trzeba, iż wpisywały się one w lęk przed radykalizmem mas, typowy dla społeczeństw mieszczańskich i bardzo wyraźnie narastający w Królestwie w czasie rewolucji. Proces ten, prowadzący finalnie do swego rodzaju ,repulsji” elit w stosunku do rozbudzonych oczekiwań mas, miał swoje długofalowe konsekwencje $\mathrm{e}^{43}$.

Zupełnie przeciwstawna wizja stosunków społecznych prezentowana była natomiast przez ówczesne partie rewolucyjne i związane z nimi środowiska. Co intrygujące, na łamach „Robotnika”, pełnego przecież niezwykle zaangażowanych wystąpień krytykujących antydemokratyczne oblicze rosyjskich reform, próżno szukać liczniejszych wzmianek na temat planowanego samorządu. Myliłby się jednak ten kto by sądził, że problemy miast nie były istotne dla ruchu rewolucyjnego. Przeciwnie, to właśnie w pismach rewolucjonistów przymiotnik ,,miejski” odmieniany był przez wszystkie przypadki, a interesy proletariatu miejskiego silnie dystansowane od interesów mieszczaństwa i innych grup (klas) społecznych. Optując za demokratycznym systemem wyborczym i nawołując do utworzenia

${ }^{41}$ St. Łąp., Dom ludowy, „Rozwój” 2 XI 1907, nr 221.

${ }^{42}$ Tamże.

${ }^{43}$ Zob.: W. Marzec, K. Śmiechowski, Pathogenesis of the Polish Public Sphere. The Intelligentsia and Popular Unrest during and after the 1905 Revolution, "Polish Sociological Review" 2015 [w druku]. 
konstytuanty w Warszawie, organ Polskiej Partii Socjalistycznej jeszcze w 1905 r. silnie akcentował znaczenie polityczne wysokiego stopnia urbanizacji Królestwa.

W krajach o przeważającej ludności miejskiej, robotniczej, fabrycznej, jak Anglia, Francja, Niemcy - proletariat - pisano - odgrywa stosunkowo największą rolę. [...] Królestwo Polskie jest w porównaniu z Cesarstwem krajem bardziej uprzemysłowionym; ludność miejska jest u nas liczebniejszą i proletariatu jest stosunkowo więcej: w dodatku świadomość klasowa tego proletariatu jest starszą i głębszą, i organizacja jego lepsza. W parlamencie warszawskim proletariat odegrałby bez wątpienia większą rolę, aniżeli w parlamencie ogólno-rosyjskim, petersburskim: posłów socjalistycznych byłoby w nim zapewne stosunkowo więcej, i przedstawiciele wsteczniejszej ludności wiejskiej nie w tym stopniu przeważaliby nad przedstawicielami bardziej postępowej ludności miejskiej ${ }^{44}$.

Bardzo podobną argumentację stosował również Edward Chwalewik, autor wydanej w 1906 r. w ramach serii Biblioteka Spótczesna pracy Wielkie miasta, ich rozwój, wzrost i przyszłośc ${ }^{45}$. Prezentująca skrajnie optymistyczny stosunek do urbanizacji, ta książeczka o naukowych ambicjach pozostawała w kontrze zarówno wobec liberalnej, jak i naturalistycznej, młodopolskiej formy antyurbanizmu. Ów były działacz SDKPiL, silnie związany z „papieżem” polskiego socjalizmu Ludwikiem Krzywickim, wrócił z zesłania do Warszawy w samym środku wydarzeń rewolucyjnych i - jak sądzę - nie pozostało to bez wpływu na kształt jego książki. Była ona mianowicie wielką polemiką z tymi wszystkimi, którzy twierdzili, że wielkie miasta przyczyniają się do degeneracji moralnej i wynarodowienia ludu. Niejako wpisując się w marksowską tradycję przeciwstawiania urbanizacji „idiotyzmowi życia wiejskiego” dowodził:

Wielu wyobraża sobie wielkie miasta jako piekła zarazy, gdzie, wskutek epidemii różnych i w braku czystego powietrza, setki a nawet tysiące osób padają ofiarą śmierci; wieś natomiast w oczach ogółu jest krynicą życia, arkadią idylliczną, pełną prostoty, czystości i zacisza, dokąd uciekać należy ze smrodliwych i dusznych mrowisk miejskich.

Jeżeli istotnie rażą nas w wielkim mieście, po uboższych zwłaszcza dzielnicach, brud i nędza, jeżeli uderza nas przeludnienie koszarowych domów, drwiny z niektórych warunków sanitarnych, liczne występki i pijaństwo, to z drugiej strony wprawia nas w podziw doskonale zorganizowana pomoc lekarska, straż ogniowa, szpitale, lecznice bezpłatne, pogotowia ratunkowe, wodociągi, kanalizacje, domy podrzutków itp. środki, prowadzące zorganizowaną walkę skuteczną ze śmiercią.

[...] Również i w Królestwie Polskim, pomimo całej niehigieniczności naszych miast wskutek przede wszystkim braku samorządu, wskaźnik śmiertelności miejskiej, według wyliczeń Załęskiego, jest mniejszy niż śmiertelności wsi. Okazuje się tedy, że nie tyle skupienie ludności po miastach, ile niedbalstwo i brak zamiłowania do czystości i porządku sprzyjają wysokiej śmiertelności wśród ludzi ${ }^{46}$.

\footnotetext{
${ }^{44}$ Nasze hasło polityczne, „Robotnik”, 13 XI 1905, nr 64, s. 2.

${ }^{45}$ E. Chwalewik, Wielkie miasta, ich rozwój, wzrost i przyszłość, Warszawa 1907.

${ }^{46}$ Tamże, s. 42-43.
} 
Również i wpływ urbanizacji na przyszłość kultury narodowej bynajmniej nie spędzał snu z powiek Chwalewika. Przeciwnie, był on raczej przekonany, że:

\begin{abstract}
Wobec tego i ówdzie rozlegające się obawy o naszą Warszawę, by ona, zostawszy milionowym miastem i wszechświatowym ogniskiem przemysłowo-handlowym, nie spaczyła kultury rodzimej są, naszym zdaniem, całkiem płonne. [...] Wielkie miasto spółczesne, jako miejsce dobrowolnie obranej pracy, przedstawia sobą wyższą formę współżycia społecznego i, przyczyniając się potężnie do wyrobienia w obywatelach swoich głębszego poczucia dobra, sprawiedliwości i piękna, jest pionierem szczerze kulturalnego postępu ${ }^{47}$.
\end{abstract}

Skoro socjaliści przykładali tak wielką wagę do urbanizacji czemu nie dostrzegali szansy, jaką mógłby dla nich być (i często okazywał się być w II RP) miejski samorząd? W dużej mierze odpowiedź na to pytanie wynikała ze specyficznego rozumienia miejskiej przestrzeni przez ugrupowania socjalistyczne. Miasto stanowiło dla rewolucjonistów pole walki klasowej między posiadaczami nieruchomości i zakładów przemysłowych i proletariackimi lokatorami, nie zaś pole potencjalnych sojuszy $^{48}$. Zdaniem agitatorów PPS wysuwane tak przez liberałów jak i endecję hasło autonomii Polski, w ramach której funkcjonowałyby samorządy miejskie, $\mathrm{w}$ istocie służyć miało jedynie podporządkowaniu proletariatu przez burżuazję̨ ${ }^{49}$. Grupy społeczne, z którymi przyszłoby potencjalnie współtworzyć samorząd przedstawicielom partii robotniczych, były traktowane przez nie jako wrogowie klasowi z największą nieufnością. O liberałach z Postępowej Demokracji, najgorętszych zwolennikach miejskiego samorządu, na łamach „Robotnika” pisano:

P.D. jest burżuazją tak samo, jak i jej przyrodnia siostrzyca w poprzednim artykule przez
nas scharakteryzowana. Tylko, że ta pierwsza (ugodowcy, klerykali) za teren swej dzia-
łalności obiera wielką własność ziemską i największy przemysł fabryczny. Terenem P.D.
jest miasto. Przemysłowcy fabryczni, nie najbogatsi, inteligencja z przemysłem związana
(adwokaci, rejenci, lekarze, inżynierowie itp.), nie ta inteligencja, która zalicza się do wiel-
kiej proletariackiej rodziny - oto wyznawcy „programów i demokratycznych”, smażonych
w garkuchniach „Prawdy” i „Gazety Handlowej”. [...] I P.D. na równi z ugodowcami należy
do jednej rodziny Reakcji, która ze wszystkich stron żelazną gwoździami najeżoną obręczą
opasa proletariat nasz ${ }^{50}$.

Apoteoza konfliktu stosowana w miejskim dyskursie socjalistów służyć miała oczywiście całkowitemu przemodelowaniu stosunków społecznych i z tego też punktu widzenia stanowiła punkt widzenia pozostający w kontrze wobec klasycznej, mieszczańskiej sfery publicznej i wypracowanych na jej gruncie instytucji ${ }^{51}$.

${ }^{47}$ Tamże, s. 73-74.

${ }^{48}$ P. Saunders, Urban Politics. A Sociological Interpretation, London 1979, s. 76-80.

${ }^{49}$ Marzenia autonomiczne skoncentrowanych żywiołów narodowych, „Robotnik”, 25 IX 1906, nr 183, s. 1-2.

${ }^{50}$ Zbrodnie burżuazji, cz. II, „Robotnik”, 10 I 1906, nr 72, s. 2-3.

${ }^{51} \mathrm{O}$ powstawaniu proletariackiej sfery publicznej w czasie rewolucji 1905 roku zob.: W. Marzec, K. Piskała, Proletariaccy czytelnicy - marksistowskie i socjalistyczne lektury we wczesnej proletariackiej sferze publicznej Królestwa Polskiego, ,Sensus Historiae” 2013, nr 3, s. 83-103. 
Jednocześnie trzeba podkreślić jednak, iż logika ta była nieskuteczna - jedynie rewolucja komunistyczna mogłaby przemodelować stosunki społeczne w miastach Królestwa w takim stopniu, by zmienić istniejące w nich podziały własnościowe, a i wtedy niektóre problemy, np. kwestia fatalnych warunków mieszkaniowych proletariatu pozostawałaby trudną do rozwiązania. Za to spowodowana brakiem samorządu miejskiego bardzo niska aktywności państwa na tym polu przynosiła fatalne skutki w postaci słabych efektów podejmowanych oddolnie wysiłków ${ }^{52}$.

Swoista izolacja socjalistów przy jednoczesnej nasilającej się nieprzystawalności wizji liberałów do rewolucyjnej atmosfery szybko zmieniających się uwarunkowań społeczno-politycznych prowadzić musiała do znacznego ograniczenia możliwości skutecznego skontrowania coraz silniejszej tendencji ku przesuwaniu się środka ciężkości toczonego dyskursu z kwestii społecznych na etniczne. Wprawdzie kwestia żydowska wpływała już na kształt dyskusji już podczas prac nad projektem Suligowskiego. Jak dowiadujemy się z jednego z artykułów w „Tygodniku Ilustrowanym” na pewnym etapie prac ograniczenie dotyczące umiejętności czytania i pisania zostało nawet zniesione na wniosek Samuela Dicksteina, zapewne w interesie królewiackiej diaspory, później jednak przy małej frekwencji członkowie podjęli decyzję o jego ponownym wpisaniu do projek$\mathrm{tu}^{53}$. Jednak dopiero projekt rządowy z $1909 \mathrm{r}^{54}$ był silnie osadzony w logice nie społecznej, lecz narodowościowej i nosił oblicze wyraziście antysemickie. Redukował on mianowicie liczbę radnych żydowskich do $10 \% \mathrm{w}$ miastach, w których populacja starozakonnych nie przekraczała połowy mieszkańców oraz $1 / 3 \mathrm{~W}$ miastach, w których Żydzi stanowili ponad 50\% ogółu populacji. Ponadto wprowadzona została kuria dla wyborców rosyjskich, którzy - poza wojskiem i wyższą administracją - w miastach Królestwa byli bardzo nieliczni. Od samego początku zakładano też ograniczanie języka polskiego, które w późniejszych dyskusjach w coraz bardziej reakcyjnych izbach rosyjskiego parlamentu szybko zaczęło ewoluować w kierunku jego całkowitego wyrugowania. Wizja kurii narodowościowych była całkowicie nie do zaakceptowania dla ugrupowań demokratycznych nie wspominając już o socjalistach, szybko została podchwycona jednak przez endecję, która od samego początku widziała samorząd miejski wyłącznie jako środek umacniania kultury polskiej w ośrodkach miejskich Królestwa ${ }^{55}$.

${ }^{52}$ Zob.: K. Śmiechowski, Warunki mieszkaniowe robotników na łamach „Gońca Łódzkiego” (1898-1906), „Studia z Historii Społeczno-Gospodarczej XIX-XX wieku” 2012, t. 10, s. 105-120.

${ }^{53}$ Ang. Tar., Samorzą miejski, „Tygodnik Ilustrowany”, 28 VII 1906, nr 30, s. 586.

${ }^{54} \mathrm{~A}$. Suligowski, Rozbiór projektu ustawy miejskiej wniesionego przez rząd do dumy państwowej w roku 1910, [w:] tenże, Potrzeba samorzadu ..., s. 213-245.

${ }^{55}$ Losy projektu w Dumie Państwowej i Radzie Państwa oraz ewolucję stanowisk poszczególnych stronnictw w tej sprawie na czele z rosnącym sceptycyzmem Narodowej Demokracji wiodącym do podsycania nastrojów antysemickich omawia szczegółowo T.R. Weeks, Nationality and Municipality: Reforming City Government in the Kingdom of Poland, 1904-1915, "Russian History", t. 21 (1994), nr 1, s. 23-47. 
Późniejsze losy projektu, który - przy wsparciu liderów Narodowej Demokracji - w trakcie prac parlamentarnych stawał się coraz bardziej antysemicki, a za sprawą szalejącej w Rosji porewolucyjnej reakcji - zarazem coraz bardziej antypolski, zbiegły się z czasie z triumfem wizji prezentowanej przez endecję, która z solidarystycznej, obliczonej na integrowanie społeczeństwa wokół pewnych idei zaczęła ulegać diametralnej przemianie ku polaryzacyjnej, zorganizowanej wokół stwarzającego równie silne niebezpieczeństwo, choć zarazem rozumianego zupełnie inaczej niż u socjalistów, polsko-żydowskiego konfliktu narodowościowo-ekonomicznego o nasilającym się podłożu rasistowskim ${ }^{56}$.

I choć takie rozstrzygnięcie wydaje się łatwo akceptowalne w ogólnej logice radykalnej modernizacji, dokonującej się przecież na ziemiach polskich na początku XX w., otwartym należy pozostawić pytanie czy szczególnie silna intensywność dokonujących się wówczas podziałów w rozmaitych kwestiach społeczno-politycznych, ich trwałość i dramatyzm ich późniejszych konsekwencji, uwidoczniona nawet na poziomie dyskusji na temat samorządu miejskiego, nie był zbyt wygórowaną ceną za osiągnięcie przez polskie społeczeństwo wspomnianej na początku gotowości do demokracji. W swojej najnowszej, niezwykle inspirującej książce Tomasz Kizwalter pisze:

\begin{abstract}
Przypadek Polski, dla Polaków ważny oczywiście sam w sobie, rozpatrywany na tle europejskim pokazuje, jakie problemy wiązały się z połowicznością modernizacji, uwarunkowaną brakiem lub słabością państwa narodowego oraz niedorozwojem kultury mieszczańskiej. Ogólnoeuropejski kryzys narodowego modelu państwa i mieszczańskich wzorców kulturowych - zjawisko wyraźnie widoczne pod koniec XX wieku - w połączeniu z procesami globalizacji sprawił, że pod znakiem zapytania stanęły dotychczasowe mechanizmy kreowania społecznego porządku w warunkach demokratyzacji ${ }^{57}$.
\end{abstract}

Trudno nie zgadzać się z tą opinią. Warto jednak, na podstawie dość pesymistycznych wniosków wypływających z opisanych wyżej dyskusji, zadać pytanie czy owe „mechanizmy kreowania społecznego porządku” nie były od samego początku skażone właśnie pewnymi niedostatkami demokratyzmu, samemu rodząc problemy, z którymi później musiały się mierzyć. Dyskurs będący przedmiotem tego artykułu zdaje się bowiem pokazywać, że w systemie polityki opartej o doktryny ideowe to, co powinno stanowić istotę prowadzonych rozważań, tj. mieszkańcy miast, ich potrzeby i aspiracje oraz rozwój społeczno-gospodarczy poszczególnych ośrodków, ustępowało miejsca z góry przyjętym strukturom myślenia ideologów i działaczy politycznych.

${ }^{56}$ Zob.: K. Zieliński, Stosunki polsko-żydowskie na ziemiach Królestwa Polskiego w czasie pierwszej wojny światowej, Lublin 2005, s. 39-101.

${ }^{57}$ T. Kizwalter, W stronę równości, Kraków 2014, s. 186. 


\section{Kamil Śmiechowski}

\section{HIERARCHY OR DEMOCRACY? THE VISION OF URBAN SOCIAL ORDER IN THE KINGDOM OF POLAND (ACCORDING TO THE DISCUSSION ABOUT PLANNED URBAN MUNICIPALITY DURING THE REVOLUTION OF 1905)}

After the collapse of the January Uprising in 1863 the Kingdom of Poland experienced rapid industrialization and urbanization. When Warszawa, Łódź, Zagłębie and some smaller places became big industrial areas the ratio of urban population grew from $10 \%$ in 1870 s to $30 \%$ in 1900 . The scale of urbanization caused important social and political changes. The Revolution of 1905, considered as the first "urban revolution" in Eastern Europe was a result of those processes and initiated the era of modern politics and political discourse in Poland. One of new phenomena was an interesting discussion about planned urban municipality which was held between 1905 and 1907. The author analyses legal acts, press articles form Warszawa and Łódź and other sources in order to define three logics of urban social order presented by different political options and ideologists.

The oldest of them was the bourgeois one, which dependent the law of voting in urban elections and running in urban councils on the level of education and property to guarantee the dominant position of intelligentsia in the municipality. This argumentation presented by Adolf Suligowski, the author of the draft of new law from 1906, was criticized by members of Endecja and socialists who were convinced to their own logics of urban social order. While first of them considered urban population as divided between different nationalities, in socialists logic cities was mainly a battlefield between antagonist social classes and were not interested in cooperation with different groups.

All this ideological divisions led to final failure of the Suligowski's draft and enabled the Tsarist administration to overemphasize ethnic problems in Kingdoms urban areas and established the conflict between Poles and Jews the main principle of the new drafts. This helped Endecja, which turned during the Revolution from democratic movement into a xenophobic national party, to became the most influential party and established nationalistic logic of urban social order the most influential. 